\title{
Kendala Laten Liberalisasi Ekonomi Indonesia
}

\author{
Oleh Suwarsono
}

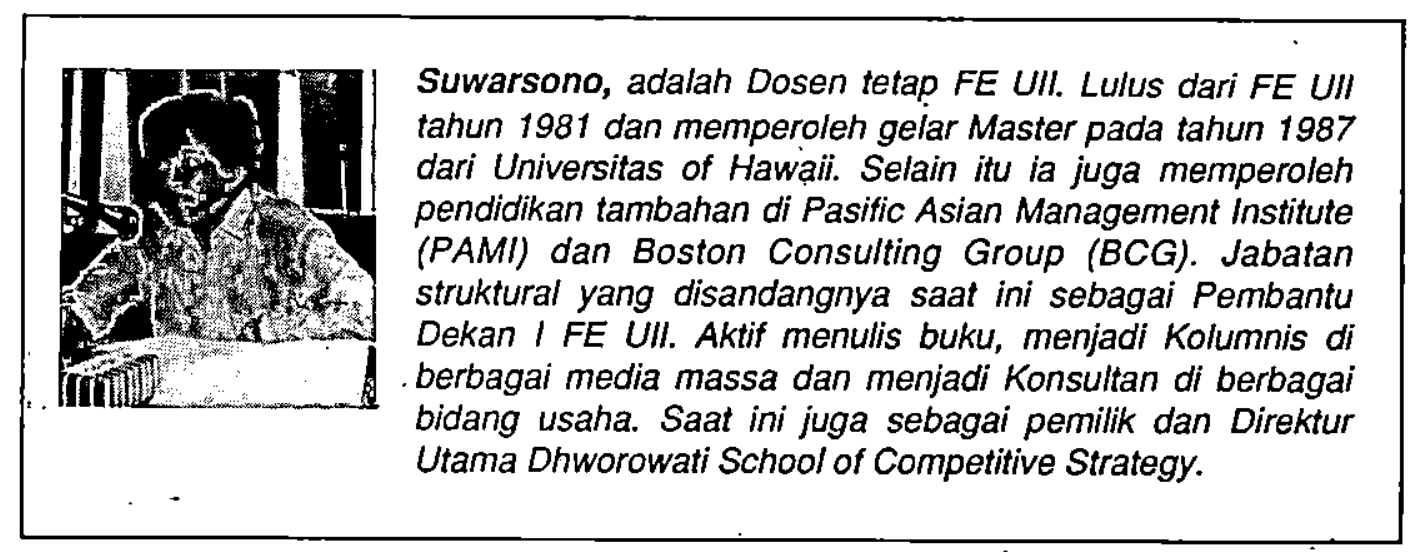

\section{Pengantar}

Sekarang ini agaknya sudah bukan saatnya lagi membicarakan perlu tidaknya liberalisasi ekonomi. Juga bukan lagi momentum yang tepat untuk membahas untung-rugi (apa dan .siapa) yang ditimbulkannya: Bahkan, tidak lagi tersedia waktu yang cukup untuk mengkaji secara mendalam kesiapan ekonomi Indonesia menyongsong ekonomi dunia yang telah semakin liberal. Kini ekonomi Indonesia seakan-akan mendadak telah berada di tengah-tengahnya. Sepertinya tidak ada lagi pilihan, sekalipun tidak perlu sampai percaya benar terhadap tafsir ekonomis terhadap tesis "the end of history". Tak ada lagi jalan untuk mundur ke belakang.

Oleh karena itu, tidak heran sejak tahun 1983 secara perlahan-Iahan dan bertahap berbagai kebijakasanaan deregulasi (baca: liberalisasi) ekonomi Indonesia terus bergulir, hampir tidak henti. Pemerintah berusaha membuat ekonomi Indonesia semakin transparan. Proses pengambilan keputusan ekonomi semata-mata ditentukan oleh mekanisme keseimbangan penawaran dan permintaan.

Hasilnya? Temyata setelah berjalan 13 tahun, masih sering kita dengar berbagai ungkapan yang menggambarkan kurang berhasilnya paket deregulasi yang telah dijalankan tersebut. Ada yang mengatakan dengan penilaian: deregulasi setengah hati, deregulasi tidak ajeg, dari deregulasi kembali ke deregulasi.

\section{Kendala Struktural}

Penilaian tersebut tidak sepenuhnya keliru. Akibat positif dan dampak negatif yang menyertainya memang tidak dapat dilihat dalam waktu segera, karena adanya kesenjangan waktu (time lag). Tidak dapat sesaat. Akan tetapi, hendaknya juga perlu disadari bahwa deregulasi ekonomi Indonesia memiliki berbagai kendala struktural, untuk tidak pemenyebut sebagai penyakit. Terkesan kendala tersebut bersifat laten, istilah yang sama yang digunakan untuk menyebut kronis (menahun) bagi penyakit. Sekiranya berbagai kendala tersebut dapat dicermati dan kemudian ditindaklanjuti dengan upaya pengurangan, bukan mustahil dan ada harapan yang lebih besar roda liberalisasi ekonomi akan berjalan lebih cepat, atau terus berjalan seiring dengannya.

Dilihat dari ukuran sejarah, waktu tiga belas tahun deregulasi masih teramat pendek dibanding dengan sejarah ekonomi Indonesia pasca kemerdekaan. Apalagi jika dibandingkan dengan keseluruhan rentang waktu sejarah ekonomi Indonesia. Rasanya tidak berlebihan jika dikatakan bahwa rentang waktu sejarah ekonomi Indonesia lebih banyak diisi dengan paradigma ekonomi yang lebih berkarakter ekonomi terpimpin (baca: sosialisme) dibanding dengan ekonomi liberal. Ideologi keadilan menjadi panglima. Oleh karena itu, tidak heran jika peran negara menjadi begitu dominan. Intervensi yang dilakukan terhadap proses pengambilan keputusan ekonomi menjadi tidak terelakkan, sampai ketika kini telah berada pada zaman deregulasi.

Keterlibatan negara yang berlebihan, bahkan, dianggap sebagai kewajaran. Apalagi jika dikaitkan dengan kemungkinan perlu diciptakan mekanisme pemberian ganjaran kepada mereka yang telah berjasa memerdekakan dan membangun negara. Sebuah alasan 
politis yang sulit ditolak dan dengan mudah akan mendapat permakluman. Oleh karena itu, keterlibatan negara seakan-akan telah menjadi kebudayaan bemegara, bukan sekedar tradisi.

Celakanya, di sisi lain tidak diimbangi dengan tradisi pengawasan penyelenggaraan bemegara yang sepadan. Sulit untuk mengatakan bahwa demokrasi dalam pengertian modern telah menjadi bagian yang integral dari sejarah kehidupan bernegara, apalagi jika dikaitkan dengan tradisi pemerintahan pada masa pra kemerdekaan. Konsekuensinya, pengurangan peran negara menjadi sesuatu yang problematik. Siapapun tahu bahwa merubah kebudayaan bukanlah pekerjaan mudah dan hampir pasti memerlukan waktu yang relatif panjang. Dan jangan lupa pasti ada resistensi, baik karena alasan ekonomis, teknologis, kebudayaan, dan politik.

Disamping itu, ada alasan ekonomis yang tidak kalah mendukung. Ekonomi. Indonesia masih cukup sering diisi oleh tidak bekerjanya mekanisme pasar, bukan saja pada masa lalu yang jauh, akan tetapi juga sampai pada masa kekinian ketika arus liberalisasi terus menguat. Perubahan harga barang dan jasa nampaknya tidak semata-mata ditentukan olch perubahan permintaan dan penawaran. Demikian pula munculnya pcluang dan ancaman bisnis yang datang dari lingkungan bisnis. Kadang-kadang ada "grey area" yang hanya bisa dimengerti ketika variabel politik dipertimbangkan. Dalam skala yang lcbih jauh, situasi banyak yang demikian menjadikan kecenderungan (trend) ckonomi menjadi sulit diprediksikan. Secara spesifik, keterlibatan variabel non-ekonomi juga menjadi penyebab kctidakpastian iklim investasi di Indonesia.

Jika mekanisme pasar berjalan lancar, ketika suku bunga deposito mengalami penurunan, selayaknya suku buka pinjaman juga mengikuti. Hal tersebut masih sulit terjadi di Indonesia. Suku bunga pinjaman baru turun setelah pemerintah melakukan intervensi, memaksa mendekatkan "spread" yang terlalu lebar. Jika keseimbangan penawaran dan permintaan berpengaruh terhadap proses penentuan harga, maka jaminan cukupnya persediaan semen yang diberikan oleh produsen semestinya tidak menyebabkan kelangkaan dan mahalnya harga. Hal tersebut juga tak tcrjadi di Indonesia. Yang terjadi justru sebaliknya, yang pada gilirannya menyebabkan orang tidak tahu. apa sesungguhnya menjadi penyebab kelangkaan dan tingginya harga semen.

Contoh lain yang terbaru dapat ditemukan pada lahimya program Mob Nas. Sepertinya pemerintah secara mendadak, mengejutkan, dan amat berani mengambil resiko kemungkinan pengurangan penerimaan pendapatan negara dari PPn BM (pajak penjualan barang mewah) dan bea masuk impor komponen, ketika kini sesungguhnya pemerintah amat membutuhkan penerimaan pendapatan dari pajak. Penyebabnya tentu saja bukan terletak sepenuhnya pada persoalan ekonomi semata. Disaat yang sama, kebijaksanaan tersebut dapat ditafsirkan sebagai bukan deregulasi ekonomi, tetapi lebih merupakan regulasi ekonomi, jika kesempatan yang sama temyata tidak diberikan kepada pihak lain yang juga memenuhi syarat sebagai industri mobil nasional.

Akan tetapi hendaknya jangan dilupakan bahwa program Mob Nas tersebut hampir dapat dipastikan mendapat dukungan yang meluas. Bagaimana tidak? Rakyat banyak diuntungkan, dengan kemungkinan harga mobil yang murah yang dapat terjangkau, yang sudah amat lama ditunggu-tunggu. Disisi lain, dukungan yang meluas tersebut juga muncul karena sepertinya ada sentimen kepada orang kaya (baca: konglomerat) yang selama ini dinilai telah menikmati kemudahan berlcbihan. Rakyat bergembira karena kemudahan tidak lagi berada di tangan mereka. Bahkan kebijaksanaan tersebut mungkin saja ditafsirkan sebagai salah satu indikator bergesemya pemihakan. Oleh karena itu, hampir tidak ditemukan komentar politis yang minor, terkecuali soal kemungkinan pilihan bias. Jadi, dalam kasus ini, dimensi politik nampak begitu dominan, baik pada aras pengambil keputusan maupun pada aras arus bawah. Jika pola pikir demikian terus mendominasi proses pegambilan keputusan ekonomi, dan bahkan terkesan bcrlebihan, bukan tak mungkin akan menjadi penghambat laju liberalisasi ekonomi.

\section{Pergeseran Struktur Pasar}

Tcrakhir dan yang tak kalah pentingnya, liberalisasi ekonomi juga membawa kemungkinan kemenangan dan kekalahan. Proses tersebut dimulai dengan bergesemya struktur pasar dari monopoli yang menuju kearah - sekalipun tak pernah sampai - pada pasar persaingan sempurna. Pada puncaknya akan muncul apa yang disebut dengan kompetisi hiper. Dalam tataran tersebut, harus dikatakan secara jelas bahwa yang menang adalah mercka yang kuat; ekonomi dan politis. Demikian scbaliknya, yang kalah adalah mereka yang lemah. Deregulasi ckonomi Indonesia dimulai ketika hanya sedikit yang kuat dan demikian banyak yang lemah. Oleh karena itu, jika komitmen keadilan tak pernah bergeser, rasanya mustahil liberalisasi akan berjalan persis seperti kcrangka ekonomi kapitalis dan kemudian kita bermimpi tak ada intervensi negara.

Jadi polanya, saya kira tak hendak berubah jauh dari "state capitalism". Justru, inilah barangkali pola yang ideal. Dengan demikian, sesungguhnya yang ada bukan semata-mata kendala laten, melainkan sebuah keniscayaan bahwa liberalisasi ekonomi Indonesia tak 
dapat dan tak perlu menghindari sejarah. Berapapun manfaat yang hendak diperoleh dari liberalisasi, rasanya masih tetap tidak cukup untuk ditukar dengan harga keadilan dan ideologi kerakyatan, sekalipun tidak juga harus mendahulukan yang disebut belakangan secara terus menerus.

Oleh karena itu, disinilah letak unsur seni pengambilan keputusan. Mereka harus terus berenang dengan lincah dan tanpa lelah menghadapi gelombang yang muncul sebagai interaksi dinamis antara liberalisasi dan ideologi kerakyatan. Keduanya sepertinya tidak lagi dan tidak perlu dipertentangkan, sama persis dengan pertumbuhan dan pemerataan. Pertumbuhan yang berkelanjutan memerlukan pemerataan. Liberalisasi ekonomi berkelanjutan memerlukan keadilan. Jika tidak, yang ada hanya kekacauan.

Akan tetapi jika pilihan tetap berpegang teguh pada "state capitalism" hanya mendasarkan diri pada sejarah, bukan mustahil yang hendak terjadi di masa depan juga sekedar pengulangan sejarah. Negara menjadi lebih dominan dibanding dengan pasar. Jịka ini terjadi, inilah tanda yang paling awal bahwa liberalisasi ekonomi akan segera mandeg, yang pada gilirannya akan menyebabkan tak berkembangnya daya saing nasional yang berujung pada kegagalan bersaing di pasar global.

Bukan itu saja, pertemuan negara dengan pasar bisa menjadikan dua kekuatan, yakni politik dan ekonomi menjadi satu, yang secara otomatis akan menjadikan posisi tawar menawar negara vis-a-vis masyarakat akan jauh lebih tinggi. Akibatnya masyarakat sipil yang demokratis (civil society) yang sudah lama diimpikan dan selama ini mulai terbangun - sekalipun dengan langkah yang sering gontai - menjadi mundur kebelakang. Politik dan kekuasaan memiliki peluang menjadi panglima. Biaya yang teramat mahal.

Oleh karena itu pengertian "state capitalism" harus diberi catatan kaki banyak, tidak sekedar bergulir seperti yang selama ini pernah terjadi. Catatan yang terpenting adalah perlu pendefinisian ulang tentang apa yang dimaksud dengan pengertian penguasaan sebagian sektor dalam ekonomi oleh negara. Adakah yang demikian selalu berarti pemilikan? Nampaknya, jawabnya: jelas tidak. Oleh karena itu, peran negara lebih pada soal kebijaksanaan ekonomi. Sekiranya demikian, sejak dini perlu disadari bahwa yang kini dikenal sebagai Badan Usaha Milik Negara (BUMN) dan Badan Usaha Milik Daerah (BUMD) tidak selalu menjadi bentuk pilihan badan usaha, tanpa ada altematif yang lain, yang masih perlu dikaji lebih jauh.

Namun demikian, pengertian negara hanya berperan pada perumusan kebijaksanaan ekonomi juga telah sering menimbulkan distorsi. Tidak hanya pada masa lalu yang jauh, akan tetapi juga sampai pada masa kekinian. Masih saja terbuka peluang yang cukup lebar untuk mencoba kembali pada ekonomi regulasi dan oleh karena itu masih mensisakan ruang untuk terjadinya mekanisme ekonomi rente.

Jika demikian halnya, sejak dini perlu ada seperangkat aturan (hukum) yang secara ketàt mengatur mekanisme persaingan ekonomi dan sekaligus mengatur pembagian ladang dan sawah ekonomi (bukan kue ekonomi). Dengan kalimat yang lebih jelas, perwujudan seperangkat-hukum yang serupa dengan undang-undang anti trust, dalam pengertian yang seluas-luasnya, menjadi tak terelakkan. Bahkan menjadi prasyarat pendahuluan. Kesepakatan politik dan dorongan moral saja tetap tidak memadai. Bahkan bisa menjadi sumber perasaan berhutang budi, yang pada gilirannya juga menuntut pembayaran, yang jauh lebih mahal dan bisa berkepanjangan.

Adakah catatan kaki yang lain ? Jawabnya juga jelas : masih ada. Kini giliran pembaca yang menambahkan. Tidakkah demikian yang disebut dengan demokrasi ? Setidaknya untuk pengertian yang paling elementer.

\section{Daftar Pustaka}

Amsden, Alice, H. 1989. Asia's Next Giant, South Korea and Late Industrialization. New York : Oxford University Press.

Drucker, Peter F. 1995. Managing in a Time of Great Change. Singapore :Heinemann.

Fitzgeral, Robert. ed. 1994. The Competitive Advantages of Far Eastern Business. Singapore : Toppan Company (PTE) Limited.

Fukuyama, Francis. 1992. The End of History and the Last Man. New York : Avon Books.

Fukuyama, Francis. 1995. Trust, The Social Virtues and the Creation of Prosperity. London : Hamish Hamilton.

Haggard Stephan dan Ching-in Monn, ed. 1989. Pacific Dynamics, The International Politics of Industrial Change. Colorado: Westview Press.

Kanter, Rosabeth Moss. 1995. World Class, Thriving Locally in the Global Economy. New York : Simon \& Schuster.

World Bank. 1993. The East Asian Miracle, Economic Growth and Public Policy. New York : Oxford University Press. 